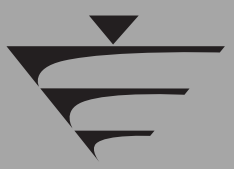

\title{
Discussion: A unique structure of Scammonden dam
}

Anthea Peters BEng (Hons), MSc (DIC), CEng, FICE

Associate, Arup, Leeds, UK

Newman Booth

Principal Engineer Reservoirs, Yorkshire Water Services Ltd, Bradford, UK
Jane Winder

Waverley, Surrey, UK

\section{Contribution by J. Winder}

My father A. J. H. (John) Winder was delighted to see his name on a short list of the BDS members from 50 years ago.

He was however disappointed not to be mentioned in your excellent paper on Scammonden Reservoir, in the same journal (Peters and Booth, 2016). As the Chief Resident Engineer, it was one of his proudest achievements.

A. J. H. Winder worked for Binnie and Partners, where he was the Chief Resident Engineer on the Great Ouse Water Scheme, later called Grafham Water, opened by the Duke of Edinburgh on 6 July 1966. He then worked for Herbert Lapworth Partners and was made the Chief Resident Engineer on Scammonden dam in September 1966. Some years later he wrote the following account on his 4 years working on the project

It was to be one of the highest dams in the UK, constructed from rock fill removed from the bottom of the valley with a wide sloping clay core, and a bypass tunnel into the side of the valley to divert the stream in the bottom, and later, as an outlet for the reservoir. It was a massive scheme.

The work on site, with Sir Alfred McAlpine and Son, the main contractors, went well. A lot of alterations had to be made to the design in the original drawings to conform to conditions found on site and I was again lucky to have an excellent supporting staff, including the late David Evans, my 'second in command' and Al Dhahir, an excellent Soil Mechanics specialist, three inspectors and a secretary, Ruth Clay, a local girl who later married one of our engineers (and also worked for me on the site at Rutland Water as my secretary)

In spite of many difficulties, the job was finished on time: the dam was complete, and the reservoir filling up. As Britain's first mountain motorway, the M62 had still to be completed.

The motorway (which was carried across the valley on the crest of the dam), the dam and reservoir were formally opened by H.M. the Queen on 14 October 1971, and I was presented to Her Majesty at that time, with a group of officials involved with the project. The Queen was very friendly and asked me about any problems and if materials had to be imported.

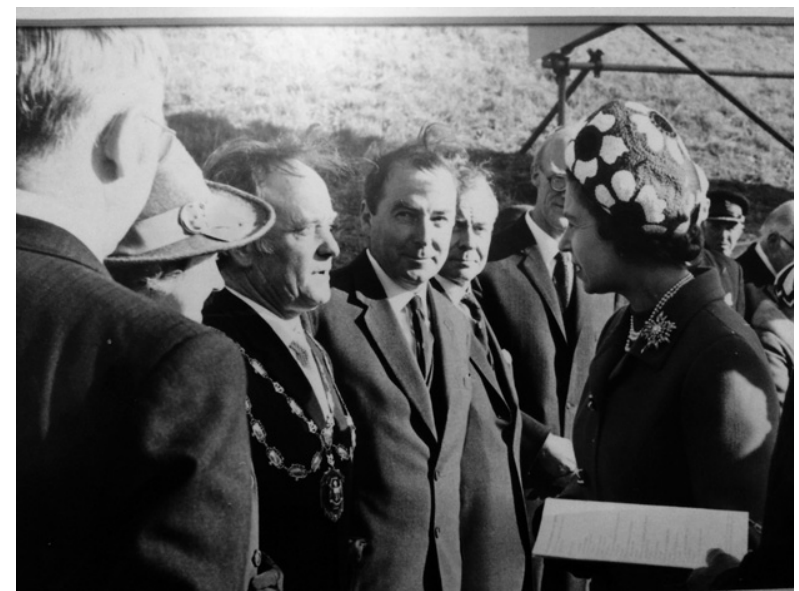

Figure 1. A. J. H. (John) Winder (centre) at the opening of Scammonden Reservoir with the Queen

I attach a photograph of this proud day (Figure 1) - my father is seen next to the Mayor of Huddersfield, with the Queen.

My father went on to be the Chief Resident Engineer on Rutland Water, and after that became a consultant/inspecting engineer with Watson and Hawksley on many projects around the world.

He lives with his wife, Cherry, at home in Surrey. Apart from a poor memory, he is in pretty good health and turned 95 years in October 2016.

\section{Author's reply}

I would like to thank J. Winder for getting it touch and giving a more personal account of the construction of Scammonden dam by her father. It is an incredible structure and I can understand why it is one of his proudest achievements to have worked as the Chief Resident Engineer. I am personally very inspired by previous generations of dam engineers in our country and in what they have achieved.

\section{REFERENCE}

Peters A and Booth N (2016) Scammonden dam: an unique structure. Dams and Reservoirs 26(2): 99-105, http://dx.doi.org/10.1680/ jdare.16.00030. 